\title{
EVALUASI KEPUASAN MASYARAKAT TERHADAP PELAYANAN PUBLIK PEMERINTAH DESA GUNUNGGEDE KECAMATAN WONOTIRTO KABUPATEN BLITAR
}

\author{
Eko Adi Susilo \\ Fakultas Ilmu Sosial Dan Ilmu Politik, Universitas Islam Balitar \\ Email: edisusilo77@gmail.com
}

\begin{abstract}
Based on the background of the problems described above, the authors formulated the problem in this study is how community satisfaction with public services in Gununggede Wonotirto Kabupaten Blitar. The purpose of this study was to find out how community satisfaction with public services in Gununggede Wonotirto Blitar. Based on the discussion described, it can be concluded that community satisfaction with public services in Gununggede Wonotirto Blitar is very good, and the community also felt very satisfied with the service provided by the office. Although the service can be said to be very good, but the services in Gununggede Wonotirto Blitar will continue to improve the quality of services to the village community by adding facilities and infrastructure so that the community feels comfortable and at home in Gununggede Office Wonotirto Blitar
\end{abstract}

\section{Keywords: Evaluation, Community Satisfaction, Public Service}

\section{PENDAHULUAN}

Pelayanan publik pada masyarakat desa merupakan suatu tugas penting oleh pemerintah desa sebab jika komponen pelayanan terjadi stagnasi maka hampir dipastikan semua sektor akan berdampak kemacetan oleh sebab itu perlu ada perencanaan yang baik dan bahkan perlu di formulasikan standar pelayanan pada masyarakat sesuai dengan kewenangan yang diberikan oleh pemerintah. Kualitas pelayanan yang baik merupakan salah satu faktor penting dalam usaha menciptakan loyalitas. Layanan dapat dikatakan baik atau berkualitas apabila layanan yang diberikan dapat memuaskan para pelanggannya. Oleh karena itu, suatu kualitas pelayanan dapat dikatakan bermutu adalah yang akan membuat masyarakat merasa puas terhadap pelayanan yang telah diberikan pemerintah Desa sehingga secara langsung dapat membuat masyarakat puas dan percaya.

Era sekarang adalah era pelayanan publik. Pemerintah pusat dan pemerintah daerah (provinsi, kabupaten, dan kota) dalam setiap program 
kegiatannya senantiasa berupaya dan berusaha memberikan pelayanan terbaik kepada masyarakatnya.

Fungsi utama pemerintahan adalah memberikan pelayanan, menyelenggarakan pembangunan dan menyelenggarakan pemerintahan untuk mengatur dan mengurus masyarakatnya, dengan menciptakan ketentraman dan ketertiban yang mengayomi dan mensejahterakan masyarakatnya.

Penyelenggaraan pelayanan publik memiliki aspek dimensional, oleh karena itu dalam pembahasan dan menerapkan strategi pelaksanaannya tidak dapat hanya di dasarkan pada suatu aspek saja, misalnya hanya aspek ekonomi atau aspek politik saja.

\section{METODE PENELITIAN}

\section{Jenis Penelitian}

Jenis penelitian ini adalah kualitatif, peneliti menggunakan paradigma Non Positivisme/Naturalistik/Interpretatif.Paradigma Interpretatif bertujuan untuk memahami makna perilaku, simbol-simbol, dan fenomena-fenomena.Paradigma ini menekankan hakekat kenyataan sosial yang didasarkan pada definisi subjektif dan penilaiannya.

\section{Teknik Pengambilan Sampel}

Dalam penelitian Kualitatif ini yang digunakan adalah teknikPurposive Sampling. Purposive sampling yaitu teknik mencakup orang-orang yang diseleksi atas dasar kriteria-kriteria tertentu yang dibuat periset berdasarkan tujuan riset. (Sugiono : 2005). Adapun yang menjadi informan atau key informan yang dipilih untuk mendapatkan informasi dan data yang diperlukan dalam penelitian ini kriterianya adalah :

1. Kepala Desa

2. PerangkatDesa

3. Masyarakat Desa

Dan sampel yang dianggap sesuai dengan kriteria tersebut diatas adalah:

1. Kepala Desa Gununggede Kecamatan Wonotirto Kabupaten Blitar 
2. Kaur Desa Gununggede Kecamatan Wonotirto Kabupaten Blitar

3. Masyarakat DesaGununggede Kecamatan Wonotirto Kabupaten Blitar

\section{Lokasi dan Waktu Penelitian}

Penelitian ini akan dilaksanakan pada tanggal 12 Juni 2018 sampai dengan 12 Agustus 2018 di Kantor Desa Desa Gununggede Kecamatan Wonotirto Kabupaten Blitar dengan alamat Jalan Kendalisodo No. 42 Desa Gununggede Kecamatan Wonotirto Kabupaten Blitar.

\section{Teknik Analisa Data}

Analisis data merupakan suatu proses mengatur urutan data,mengorganisasikannya ke dalam suatu pola, kategori, dan satuan urutan dasar. Dari pendapat tersebut dapat dikatakan bahwa analisa data dilakukan untukmengetahui mana data yang diperlukan dan mana data yang tidak diperlukansehingga hasil penelitian benar-benar akurat dan bisa dipertanggungjawabkan.

\section{HASIL DAN PEMBAHASAN}

\section{Gambaran Umum Tempat Penelitian}

Desa Gununggede Kecamatan Wonotirto Kabupaten Blitar merupakan sebuah desa yang berada di daerah pedesaan dengan ketinggian 800 sampai dengan $900 \mathrm{~m}$ dari permukaan laut. Dengan curah hujan rata-rata pertahun antara 1000 sampai dengan $2000 \mathrm{~mm}$ dan dengan suhu rata-rata antara $20^{\circ} \mathrm{C}-24^{0 \mathrm{C}}$.

Dalam pembagian kewilayahan Desa Gununggede Kecamatan Wonotirto Kabupaten Blitar terbagi menjadi 4 (empat) wilayah dusun, antara lain:
a. Dusun Sumberbendo
b. Dusun Kali Kuning
c. Dusun Kali Kenongo
d. Dusun Krajan

\section{Kondisi Sosial Ekonomi dan Budaya Masyarakat}

Sesuai dengan data dari Desa Gununggede Kecamatan Wonotirto Kabupaten Blitar tahun 2015, hampir 45\% penduduk yang bermata pencaharian 
sebagai petani dan $40 \%$ penduduk sebagai buruh tani, sisanya berprofesi sebagai guru, buruh, tukang. Sumber Daya Alam (SDA) yang menjadi potensi utama usaha penduduk adalah tebu, padi, jangung dan palawija lainnya.Penduduk masih kuat dengan budaya yang ramah dan polos serta adanya hubungan antara agama yang harmonis yang membuat hubungan kerjasama menjadi lebih baik.

\section{PEMBAHASAN}

\section{Pelayanan Publik Dalam Meningkatkan Kepuasan Pelayanan Masyarakat Desa Gununggede Kecamatan Wonotirto Kabupaten Blitar}

Pelayanan publik dalam meningkatkan kepuasan pelayanan masyarakat Desa Gununggede Kecamatan Wonotirto Kabupaten Blitar pada saat ini terus dilakukan perubahan untuk meningkatkan kualitas kepada masyarakat. Pelayanan publik tentu saja akan dapat meningkatkan kualitas pelayanan publik itu sendiri Kualitas jasa

Pelanggan akan merasa puas bila hasil evaluasi mereka menunjukkan bahwa jasa yang mereka gunakan berkualitas. Konsumen rasional selalu menuntut jasa yang berkualitas untuk setiap pengorbanan yang dilakukan untuk memperoleh jasa tersebut. Dalam hal ini, kualitas jasa yang baik akan memberikan nilai tambah di benak konsumen.Dan bagaimanakah kualitas jasa pelayanan publik yang diberikan pegawai kepada masyarakat, berikut hasil wawancara dengan warga desa Desa Gununggede Kecamatan Wonotirto Kabupaten Blitar:

Bahwa selama ini pelayanan publik yang di berikan kepada masyarakat sudah cukup baik, pelayanan yang diberikan sangat cepat dan tepat pada masyarakat dan tidak ada kesalahan.

Dari hasil wawancra dengan warga desa Desa Gununggede Kecamatan Wonotirto Kabupaten Blitar bahwaselama ini pelayanan publik yang di berikan kepada masyarakat sudah cukup baik, pelayanan yang diberikan sangat cepat dan tepat pada masyarakat dan tidak ada kesalahan. Dan apakah manfaat dari pemberian kualitas jasa oleh perangkat kepada masyarakat, berikut hasil 
wawancara dengan warga desa Desa Gununggede Kecamatan Wonotirto Kabupaten Blitar:

Manfaatnya dari kualitas pelayanan jasa oleh pegawai kepada masyarakat adalah kepercayaan masyarakat kepada pegawai sehingga memudahkan memenuhi kebutuhan masyarakat.

Dari hasil wawancra dengan warga desa Desa Gununggede Kecamatan Wonotirto Kabupaten Blitar bahwa manfaatnya dari kualitas pelayanan jasa oleh pegawai kepada masyarakat adalah kepercayaan masyarakat kepada pegawai sehingga memudahkan memenuhi kebutuhan masyarakat. Kualitas jasa pelayanan publik yang diberikan pegawai kepada masyarakat, berdasarkan hasil penelitian diketahui bahwa selama ini pelayanan public yang di berikan kepada masyarakat sudah cukup baik, pelayanan yang diberikan sangat cepat dan tepat pada masyarakat dan tidak ada kesalahan.

Dan manfaat dari pemberian kualitas jasa oleh pegawai kepada masyarakat, diketahui bahwa manfaatnya dari kualitas pelayanan jasa oleh pegawai kepada masyarakat adalah kepercayaan masyarakat kepada pegawai sehingga memudahkan memenuhi kebutuhan masyarakat.

1. Kualitas pelayanan

Kualitas pelayanan terutama dibidang jasa, pelanggan akan merasa puas bila mereka mendapatkan pelayanan yang baik atau yang sesuai dengan yang diharapkan. Pelanggan yang puas akan menunjukkan kemungkinan untuk kembali memperoleh jasa yang sama. Pelanggan yang puas cenderung memberikan persepsi terhadap jasa instansi. Untuk mengetahui bagaimanakah kualitas pelayanan pegawai kepada masyarakat, berikut hasil wawancara dengan warga desa Desa Gununggede Kecamatan Wonotirto Kabupaten Blitar:

Untuk kualitas pelayanan yang diberikan oleh pegawai kepada masyarakat cukup baik, pelayanan yang ramah dan memudahkan masyarakat.

Dari hasil wawancra dengan warga desa Desa Gununggede Kecamatan Wonotirto Kabupaten Blitar bahwa untuk kualitas pelayanan yang diberikan oleh pegawai kepada masyarakat cukup baik, pelayanan yang ramah dan memudahkan masyarakat. Dan apakah yang dilakukan masyarakat jika pelayanan pegawai 
memuaskan, berikut hasil wawancara dengan warga desa Desa Gununggede Kecamatan Wonotirto Kabupaten Blitar:

Masyarakat tentunya merasa senang, dan diperhatikan sehingga masyarakat percaya

Dari hasil wawancra dengan warga desa Desa Gununggede Kecamatan Wonotirto Kabupaten Blitar bahwa masyarakat tentunya merasa senang, dan diperhatikan sehingga masyarakat percaya. Kualitas pelayanan pegawai kepada masyarakat dari hasil penelitian diketahu bahwa untuk kualitas pelayanan yang diberikan oleh pegawai kepada masyarakat cukup baik, pelayanan yang ramah dan memudahkan masyarakat. Dan yang dilakukan masyarakat jika pelayanan pegawai memuaskan diketahui bahwa masyarakat tentunya merasa senang, dan diperhatikan sehingga masyarakat percaya.

\section{Emosional}

Pelanggan akan merasa bangga dan mendapatkan keyakinan bahwa orang lain akan kagum terhadap dia bila memperoleh jasa sesuai dengan harapan cenderung mempunyai tingkat kepuasan yang lebih tinggi. Kepuasan yang diperoleh bukan karena kualitas dari jasa tetapi nilai sosial atau self esteem yang membuat pelanggan menjadi puas terhadap jasa tertentu. Dan untuk mengetahui bagaimanakah tingkat emosional pelayanan jasa yang diberikan pegawai kepada masyarakat, berikut hasil wawancara dengan warga desa Desa Gununggede Kecamatan Wonotirto Kabupaten Blitar:

Untuk tingkat emosional yang diberikan pegawai dengan masyarakat sangat empatik yaitu sangat dekat seperti keluarga sendiri.

Dari hasil wawancra dengan warga desa Desa Gununggede Kecamatan Wonotirto Kabupaten Blitar bahwa untuk tingkat emosional yang diberikan pegawai dengan masyarakat sangat empatik yaitu sangat dekat seperti keluarga sendiri. Dan apakah manfaat dari kedekatan emosional antara pegawai dengan masyarakat, berikut hasil wawancara dengan warga desa Desa Gununggede Kecamatan Wonotirto Kabupaten Blitar: 
Tentunya masyarakat akan merasa nyaman karena seperti keluarga sendiri sehingga masyarakat akan lebih terbuka untuk menyampaikan kebutuhannya. (Wawancara, 17 Juli 2017)

Dari hasil wawancra dengan warga desa Desa Gununggede Kecamatan Wonotirto Kabupaten Blitar bahwa masyarakat akan merasa nyaman karena seperti keluarga sendiri sehingga masyarakat akan lebih terbuka untuk menyampaikan kebutuhannya. Jadi tingkat emosional pelayanan jasa yang diberikan pegawai kepada masyarakat dari hasil penelitian yang dilakukan oleh peneliti diketahui bahwa untuk tingkat emosional yang diberikan pegawai dengan masyarakat sangat empatik yaitu sangat dekat seperti keluarga sendiri. Sedangkan manfaat dari kedekatan emosional antara pegawai dengan masyarakat diketahui bahwatentunya masyarakat akan merasa nyaman karena seperti keluarga sendiri sehingga masyarakat akan lebih terbuka untuk menyampaikan kebutuhannya.

3. Harga

Jasa yang mempunyai kualitas yang sama tetapi menetapkan harga yang relatif murah akan memberikan nilai yang lebih tinggi kepada pelanggannya. Untuk mengetahui apakah pelayanan pegawai sangat berharga bagi masyarakat, berikut hasil wawancara dengan warga desa Desa Gununggede Kecamatan Wonotirto Kabupaten Blitar:

Iya mba, sangat berharga karena pelayanan yang baik sangat dibutuhkan masyarakat sehingga pelayanan prima akan terwujud untuk masyarakat desa.

Dari hasil wawancra dengan warga desa Desa Gununggede Kecamatan Wonotirto Kabupaten Blitar bahwa harga sangat penting karena pelayanan yang baik sangat dibutuhkan masyarakat sehingga pelayanan prima akan terwujud untuk masyarakat desa. Dan bagaimanakah nilai jasa yang diberikan pegawai kepada masyarakat, berikut hasil wawancara dengan warga desa Desa Gununggede Kecamatan Wonotirto Kabupaten Blitar:

Pastinya sangat besar karena dengan adanya pelayanan jasa yang baik akan memberikan nilai tambah atau rasa simpatik masyarakat kepada para pegawai pelayanan publik.. 
Dari hasil wawancra dengan warga desa Desa Gununggede Kecamatan Wonotirto Kabupaten Blitar bahwanilai jasa yang diberikan pegawai kepada masyarakatsangat besar karena dengan adanya pelayanan jasa yang baik akan memberikan nilai tambah atau rasa simpatik masyarakat kepada para pegawai pelayanan publik. Jadi pegawai sangat berharga bagi masyarakat, dari hasil penelitian diketahui bahwa harga sangat berharga karena pelayanan yang baik sangat dibutuhkan masyarakat sehingga pelayanan prima akan terwujud untuk masyarakat desa. Nilai jasa yang diberikan pegawai kepada masyarakat, diketahui bahwa harga tentunya sangat besar karena dengan adanya pelayanan jasa yang baik akan memberikan nilai tambah atau rasa simpatik masyarakat kepada para pegawai pelayanan publik.

\section{Biaya}

Pelanggan tidak perlu mengeluarkan biaya tambahan atau tidak perlu membuan waktu untuk mendapatkan suatu jasa cenderung puas terhadap jasa itu.Dan apakah masyarakat mengeluarkan biaya untuk pelayanan pegawai, berikut hasil wawancara dengan warga desa Desa Gununggede Kecamatan Wonotirto Kabupaten Blitar:

Tidak ada biaya untuk pelayanan publik sehingga masyarakat lebih percaya dengan system pemerintahan desa.

Dari hasil wawancra dengan warga desa Desa Gununggede Kecamatan Wonotirto Kabupaten Blitar bahwa tidak ada biaya untuk pelayanan publik sehingga masyarakat lebih percaya dengan system pemerintahan desa. Dan apakah masyarakat mengeluarkan banyak waktu untuk menerima pelayanan pegawai, berikut hasil wawancara dengan warga desa Desa Gununggede Kecamatan Wonotirto Kabupaten Blitar:

Saya rasa tidak karena pelayanan publik yang diberikan sangat cepat dan mudah.

Dari hasil wawancra dengan warga desa Desa Gununggede Kecamatan Wonotirto Kabupaten Blitar bahwa pelayanan publik yang diberikan sangat cepat dan mudah. Sehingga masyarakat mengeluarkan biaya untuk pelayanan pegawai, dari hasil penelitian diketahui bahwa tidak ada biaya untuk pelayanan publik 
sehingga masyarakat lebih percaya dengan system pemerintahan desa. Masyarakat mengeluarkan banyak waktu untuk menerima pelayanan pegawai, dari hasil penelitian di ketahui bahwa tidak ada biaya karena pelayanan publik yang diberikan sangat cepat dan mudah.

Jadi pelayanan publik dengan beberapa indikator tersebut diatas akan meningkatkan kepuasan pelayanan masyarakat di Desa Gununggede Kecamatan Wonotirto Kabupaten Blitar. Maka dari itu diketahui dari hasil penelitian bahwa pelayanan publik dalam meningkatkan kepuasan pelayanan masyarakat di Desa Gununggede Kecamatan Wonotirto Kabupaten Blitar sangat baik dengan terus meningkatkan mutu pelayanan terhadap masyarakat desa menjadi pelayana prima.

\section{PENUTUP}

\section{Kesimpulan}

Berdasarkan pembahasan yang telah diuraikan, maka dapat disimpulkan bahwa kepuasan masyarakat terhadap pelayanan publik diDesa Gununggede Kecamatan Wonotirto Kabupaten Blitaradalah sudah sangat baik, dan masyarakatpun juga merasa sangat puas dengan pelayanan yang di berikan oleh perangkat kantor Desa Gununggede Kecamatan Wonotirto Kabupaten Blitar. Meskipun dalam pelayanan sudah bisa dibilang sangat baik, akan tetapi pelayanan yang ada di Desa Gununggede Kecamatan Wonotirto Kabupaten Blitar akan terus meningkatkan mutu pelayanan terhadap masyarakat desa dengan penambahan sarana dan prasarana agar masyarakat merasa nyaman dan betah berada diKantor Desa Gununggede Kecamatan Wonotirto Kabupaten Blitar.

\section{Saran}

a. Terus adanya inovasi dan kreatifitas dalam meningkatkan pelayanan publik kepada masyarakat sehingga masyarakat akan merasa senang, nyaman dan terlayani dengan baik.

b. Peningkatan sumber daya manusia para pegawai dengan memberikan pelatihan, seminar, dan juga bimtek untuk meningkatkan ketrampilan dan profesionalisme kerja. 


\section{DFTAR PUSTAKA}

Arikunto, Suharsimi. 2006. Prosedur Penelitian: Suatu Pendekatan. Reneka Cipta. Jakarta

Aswar, Saifuddin. 2004. Metode Penelitian. Pustaka Pelajar. Yogyakarta

Hamidi, 2004.Metode Penelitian Kualitatif, UMM Press, Malang

Hardiyansyah, 2015.Komunikasi Pelayanan Publik Konsep dan Aplikasi, Yogyakarta, Penerbit Gava Media

Heriyanto, 2014. Persepsi Masyarakat Terhadap Kualitas Pelayanan Publik Pada Bagian Administrasi Kesejahteraan Rakyat Pemerintahan Kabupaten Gunungkidul DIY, Universitas Negeri Yogyakarta

Ismerisa, 2013.Pengaruh Pelayanan Terhadap Kepuasan Pelanggan (Survey pada Pelanggan Listrik Pintar PT PLN (Persero) Area Yogyakarta, UIN Sunan Kalijaga Yogyakarta 